\title{
KÊTÊG
}

Jurnal Pengetahuan, Pemikiran dan Kajian Tentang Bunyi

Vol. 21., No. 2, November 2021, hal. 171-185

ISSN 1412-2065, eISSN 2714-6367

https://jurnal.isi-ska.ac.id/index.php/keteg

(3) -

\section{GARAP KARAWITAN PAKELIRAN; \\ PAKELIRAN SANDOSA LAKON KEMBANG KUDHUP PUPUS (Perspektif Estetika Pakeliran Nuskma dan Mungguh)}

\author{
Catur Nugroho \\ Jurusan Pedalangan, \\ Institut Seni Indonesia Surakarta, \\ Jl. Ki Hadjar Dewantara No 19 Kentingan, \\ Jebres, Surakarta (57126), Jawa Tengah, \\ Indonesia \\ caturpedalangan@gmail.com
}

\author{
Ananto Sabdo Aji* \\ Jurusan Karawitan, \\ Institut Seni Indonesia Surakarta, \\ Jl. Ki Hadjar Dewantara No 19 Kentingan, \\ Jebres, Surakarta (57126), Jawa Tengah, \\ Indonesia \\ anantosabdoaji@yahoo.com
}

dikirim 25 Februari 2022; diterima 28 Februari 2022; diterbitkan 01 Maret 2022

\begin{abstract}
Abstrak
Penelitian ini membahas mengenai garap karawitan pakeliran dalam sebuah Pakeliran Sandosa dengan Lakon Kembang Kudhup Pupus, yang ditelusuri melalui perspektif estetika dasar pakeliran yakni konsep nuksma dan mungguh. Tujuan pembahasan ini ialah untuk memahami sejauh mana sebuah unsur garap karawitan pakeliran mampu menentukan pencapaian pertunjukan wayang yang estetis. Hasil analisis menunjukan, bahwa garap karawitan pakeliran dalam Pakeliran Sandosa Lakon Kembang Kudhup Pupus dapat dipahami mencapai tataran estetika pakeliran yang mungguh. Hal demikian dapat dilihat melalui terciptanya ketepatan, keselarasan, dan kesesuaian antara komposisi garap karawitan pakeliran meliputi gendhing dan tembang terhadap kebutuhan peristiwa lakon dan suasana batin yang dialami oleh tokoh wayang. Adapun pencapaian estetika pakeliran nuksma yang mampu memotivasi kesan katarsis bagi penghayat dalam bingkai garap karawitan pakeliran dapat dirasakan melalui pola garapan melodi serta lagu gendhing dan tembang yang disusun sedemikian rupa; dengan memperhatikan kesesuaian antara teknis penyuaraan, tabuhan, dan pengaturan grafik musikal yang berorientasi pada dinamisasi rasa gendhing.
\end{abstract}

Kata Kunci: garap karawitan pakeliran, sandosa, kembang kudhup pupus, estetika pakeliran, nuksma dan mungguh.

This work is licensed under a Creative Commons Attribution-ShareAlike 4.0

\begin{abstract}
This research discusses the work of karawitan pakeliran in a Pakeliran Sandosa with story Kembang Kudhup Pupus, which is explored through the basic aesthetic perspective of pakeliran, namely the concept of nuksma and respectively. The purpose of this discussion is to understand the extent to which an element of performing karawitan pakeliran can determine the achievement of an aesthetic puppet show. The results of the analysis show that the work of karawitan pakeliran in Pakeliran Sandosa Lakon Kembang Kudhup Pupus can be understood to reach the aesthetic level of pakeliran respectively. This can be seen through the creation of accuracy, harmony, and appropriateness between the composition of the performance karawitan pakeliran including gendhing and tembang to the needs of the events of the play and the inner atmosphere experienced by the puppet. As for the achievement of the aesthetics of pakeliran nuksma which is able to motivate the effect of catharsis for the admirer in the framework of karawitan pakeliran can be felt through the pattern of melody and gendhing songs and songs arranged in such a way; by paying attention to the compatibility between vocal techniques, beats, and musical graphic arrangements that are oriented to the dynamics of the gendhing sense.
\end{abstract}

Keyword: garap karawitan pakeliran, sandosa, kembang kudhup pupus, estetika pakeliran, nuksma dan mungguh.

* Penulis Korespondensi 


\section{Pendahuluan}

Sajian pertunjukan wayang tidak dapat lepas dari sebuah konsep sebagai dasar sekaligus orientasi dalam kekaryaannya. Berbicara pada ruang lingkup garap pakeliran terdapat tiga unsur garap utama, yaitu: (1) catur, (2) sabet, dan (3) karawitan pakeliran. Catur merupakan wacana atau bahasa dalang yang digunakan dalam penyajian pertunjukannya. Adapun catur terbagi menjadi tiga hal, yaitu janturan, pocapan, dan ginem. Karawitan Pakeliran terbagi atas dhodhokan dan keprakan, sulukan, gendhing, dan tembang (Sarwanto 2008; Murtiyoso 1995). Sunardi menambahkan satu unsur garap pakeliran, yakni unsur lakon yang menitikberatkan pada sumber lakon, jenis lakon, dan struktur lakon (Sunardi 2013). Setiap unsur garap pakeliran tersebut memiliki peran dan fungsinya masing-masing yang bekerja secara sistematis dan saling terintegrasi satu sama lain. Keseluruhan unsur garap disajikan sedemikian rupa oleh dalang sebagai pemeran utama, dibantu para pengrawit serta pendukung pertunjukan lainnya sehingga menjadi sebuah kesatuan garap pakeliran yang utuh dan estetis (Nugroho 2021a). Menurut Monks dan Y Punberg, pengembangan bakat yang optimal diperlukan rangsangan dan pembinaan dari lingkungan sosial (Monks and Rahayu 2006; Aji 2020).

Pembahasan mengenai unsur garap catur dan lakon sudah cukup banyak dilakukan oleh para peniliti sebelumnya, sedangkan wacana analisis mengenai unsur garap sabet dan karawitan pakeliran masih sangat jarang dijumpai. Berkaitan dengan unsur garap sabet mungkin dipengaruhi oleh beberapa alasan, antara lain: (1) sabet yang sepenuhnya berkaitan dengan visualisasi menjadi sesuatu yang tampaknya kurang menarik apabila diteliti secara tekstual; (2) sabet dipandang sebagai suatu hal yang hanya berkutat pada persoalan teknis visualitatif sehingga kurang bermakna pada sudut pandang kontekstualnya apalagi jika disandingkan dengan catur dan lakon yang keduanya dianggap lebih kompleks; dan (3) sabet justru sebenarnya adalah sesuatu yang rumit karena sifatnya yang visual sejatinya menyimpan berbagai persoalan baik tekstual maupun kontekstual, yang sesungguhnya tidak hanya melulu persoalan teknis belaka. Adapun berkaitan dengan unsur garap karawitan pakeliran mungkin dilatarbelakangi oleh beberapa hal, diantaranya: (1) Sebagaimana fungsinya bahwa karawitan pakeliran merupakan sarana untuk menciptakan dan mendukung suasana adegan dalam pakeliran, yang artinya kurang memiliki korelasi yang kompleks terhadap kontekstual local genius masyarakat pendukung pertunjukan wayang maka kedudukannya sering dianggap sebelah mata; (2) karawitan pakeliran yang terutama berkaitan dengan gendhing sering diabaikan oleh para peneliti pedalangan karena dianggap bukan sebagai mayor bidang dan spesialisasinya; dan (3) sesungguhnya karawitan pakeliran merupakan unsur yang kompleks serta memuat berbagai konseptual maupun praktis yang melekat terhadap capaian estetika dalam pertunjukan wayang. Penyajian gending yang begitu kompleks membuat peran kendang menjadi vital sebagai pemimpin dalam sajian karawitan (Setyawan 2018), hal tersebut juga diperkuat dengan pernyataan oleh Atmojo (Atmojo 2010). Sifat musik gamelan adalah gotong royong, artinya garapan ricikan satu dengan yang lain saling mengisi, saling merespon, dan saling menginspirasi (Teguh 2017).

Berpijak pada penjelasan tersebut maka pembahasan ini berfokus terhadap analisis garap karawitan pakeliran. Dengan tanpa mengabaikan keberadaan unsur garap sabet, bahwa pembatasan pembahasan ini juga dilatarbelakangi oleh kebutuhan praktis, yakni fokus analisis seputar bunyi. Akan tetapi, selain alasan praktis pembahasan mengenai garap karawitan pakeliran memiliki urgensi yang penting dalam koridor penelitian seni baik bagi seni pedalangan maupun seni karawitan. 
Pembahasan ini mampu memperkaya kajian-kajian seputar unsur garap karawitan pakeliran yang selama ini dipandang kurang begitu diminati. Di sisi lain, kajian ini dapat menjadi stimulan terhadap kajian garap karawitan pakeliran yang dianalisis melalui perspektif estetika pedalangan secara tekstual.

Selanjutnya dibutuhkan objek material yang jelas sebagai wadah dalam melakukan pembahasan berkenaan dengan garap karawitan pakeliran. Model pertunjukan wayang terus mengalami perubahan seiring perkembangan zaman. Wayang selalu berinovasi dan beradaptasi secara kreatif terhadap fenomena-fenomena yang melingkupinya. Berkaitan dengan inovasi dan kreativitas maka model Pakeliran Sandosa menjadi salah satu jenis pakeliran yang sangat menarik untuk dicermati lebih jauh lagi. Pakeliran Sandosa merupakan salah satu bentuk pertunjukan wayang yang menggunakan Bahasa Indonesia sebagai media komunikasinya. Pakeliran Sandosa juga memiliki keunikan tersendiri dalam pertunjukannya jika dibandingkan dengan pakeliran konvensional. Pakeliran Sandosa lebih banyak mengadopsi model serta konsep dalam teater dan drama modern. Hal demikian dapat dilihat dari komposisi pelaku pertunjukan, peralatan, bentuk maupun teknik pertunjukan, konsep garap, dan unsur garap lakonnya. Pelaku dalam Pakeliran Sandosa terdiri dari sutradara, penyusun naskah, penata antawacana, narator, sulih suara, penata sabet, peraga wayang, penata iringan, pengrawit, pesinden, penata lampu, dan penata sound system. Bentuk Pakeliran Sandosa secara visual menitikberatkan pada aspek bayangan wayang yang disajikan pada layar (kelir) yang lebar dan panjang. Adapun konsep garap Pakeliran Sandosa mengacu pada konsep Pakeliran Padat, yaitu konsep kesatuan, efektivitas, efisien, dan kekinian (Sunardi 2004). Oleh karena itu, objek material dipilih Pakeliran Sandosa Lakon Kembang Kudhup Pupus karya Catur Nugroho sebagai sutradara sekaligus penyusun naskah; dan Ananto Sabdo Aji sebagai komposer atau penyusun iringannya. Video pertunjukannya dapat dilihat pada Channel Youtube Catur Nugroho melalui link berikut https://www.youtube.com/watch?v=dMQ1lbKzs-g\&t=344s. Pertunjukan Sandosa Kembang Kudhup Pupus menampilkan kisah tentang Abimanyu dalam berbagai peristiwa, baik suasana roman maupun peperangan. Pemilihan objek tersebut dengan pertimbangan bahwa terdapat sajian garap karawitan pakeliran yang menarik serta mencakup kompleksitas suasana adegan lakon yang bervariasi. Artinya, ini menjadi hal penting untuk memahami bagaimana kapasitas garap karawitan pakeliran terhadap kebutuhan-kebutuhan peristiwa lakon dan suasana batin tokoh wayang yang tampil.

\section{Konsep Nuksma dan Mungguh dalam Pakeliran}

Pembahasan ini berangkat dari asumsi bahwa Pakeliran Sandosa Lakon Kembang Kudhup Pupus menggunakan konsep Pakeliran Padat dalam sajian pertunjukannya, di dalam dunia pedalangan memiliki konsep-konsep estetikda dan dramaturgi tersendiri, misalnya regu, greget, nges, semu, dan lain sebagainya (Purwanto 2011). Oleh karenanya, pembahasan mengenai garap karawitan pakelirannya dapat dicermati melalui konsep nuskma dan mungguh. Menurut Sunardi, konsep nuksma dan mungguh merupakan konsep estetika dasar dalam pertunjukan wayang kulit purwa. Konsep tersebut dibutuhkan sebagai sistem kerangka berpikir dalam menentukan keselarasan ide atau gagasan serta kesesuaian dan ketepatan antara sesuatu yang diimajinasikan terhadap ekspresi garap dalam pakeliran. Memang, musik dan aspek-aspek atau tingkah laku lainnya dalam kehidupan manusia memiliki keterkaitan, sehingga pemahaman mengenai suatu kebudayaan dapat dicapai antara lain lewat studi terhadap musiknya (Irawati 2016). Proses pencapaian nuksma dan mungguh bagi dalang terdiri atas tiga hal penting, yaitu: (1) penguasaan 
pengetahuan dan ketrampilan teknik; (2) kemampuan garap; dan (3) kemampuan ekspresi (Sunardi 2013). Adapun unsur-unsur nuksma dan mungguh terbentuk oleh empat hal, yakni: medium, meliputi bahasa, gerak, suara, dan rupa; ekspresi, meliputi antawacana, sabetan, vokal dan instrumen; ketepatan dan keselarasan; dan daya batiniah dalang (Sunardi 2013). Berkaitan dengan ini, maka analisis nuksma dan mungguh yang berimplikasi pada keselarasan, kesesuaian, dan ketepatan ide terhadap ekspresi garap digunakan untuk melihat sejauh mana garap karawitan pakeliran dalam Pakeliran Sandosa Lakon Kembang Kudhup Pupus mencapai tataran estetis yang proporsional.

\section{Metode}

Penelitian ini bersifat kualitatif dengan menggunakan perspektif estetika dasar dalam pakeliran, yakni konsep nuksma dan mungguh. Adapun sumber data berupa video pertunjukan Sandosa dengan Lakon Kembang Kudhup Pupus yang diunggah di Channel Youtube Catur Nugroho. Video tersebut tayang pada tanggal 08 Oktober 2020 dan hingga artikel ini ditulis (November, 2021) telah ditonton sekitar 1900 views, 91 likes, dan memperoleh 56 komentar. Dalam hal ini peneliti bertindak sebagai observer partisipant. Prosedur pengumpulan data ditempuh melalui dua cara, yaitu: (1) studi pustaka dan (2) pengamatan video. Studi pustaka dilakukan untuk mencari referensi serta memperoleh pemahaman mengenai konsep dasar estetika dalam pakeliran kaitannya terhadap analisis garap karawitan pakeliran. Pengamatan video digunakan untuk mencermati jalinan peristiwa tokoh dan lakon yang tampil serta keterkaitannya terhadap garap karawitan pakeliran yang disajikan. Teknis analisis data ialah deskriptif kualitatif, yaitu analisis yang menitikberatkan pada pengambilan sudut pandang untuk menjelaskan, mendeskripsikan, serta memaparkan suatu fenomena yang diteliti sebagai penanda tertentu yang tidak dimiliki dari fenomena lain dengan sebaik-baiknya (Ahimsa-Putra 2000). Adapun analisis deskriptif dengan model interaktif menurut Miles dan Huberman sebagaimana dikutip oleh Sunardi terdiri atas tiga tahap analisis, yakni: reduksi data, sajian data, dan penarikan simpulan (Sunardi 2012).

\section{Pembahasan}

Pembahasan mengenai garap karawitan pakeliran dalam pakeliran sandosa Lakon Kembang Kudhup Pupus diawali dengan memaparkan deskripsi sajian berupa alur lakon atau alur cerita sejak awal pertunjukan sampai selesai. Hal ini penting sebagai pijakan dalam melakukan analisis garap. Deskripsi alur lakon memberikan gambaran secara umum mengenai jalannya cerita, kehadiran tokoh, terjadinya konflik, dan penyelesaian permasalahan. Metode ini juga dilakukan oleh Catur Nugroho pada penelitian udanagara tancepan yakni dengan memaparkan alur lakon terlebih dahulu untuk memetakan jalannya sajian secara runtut (Nugroho 2021b). Adapun alur lakon ditampilkan dengan ditulis setiap adegan sebagaimana yang ditampilkan dalam video pakeliran sandosa tersebut.

\section{A. Alur Lakon Kembang Kudhup Pupus}

\section{1) Adegan $I$}

Diceritakan terjadinya perang Baratayuda Jaya Binangun yakni perang besar antara Pandawa dan Kurawa. Abimanyu tampil menaiki kuda sebagai senapati Pandawa menghancurkan bala prajurit Kurawa dengan begitu gagahnya. Selanjutnya tampil Jayadrata senapati pihak 
Kurawa. Dia melepaskan senjata panah dan berhasil merobohkan Abimanyu. Kondisi Abimanyu yang roboh makin terpuruk dan mengerikan ketika para prajurit Kurawa menghujani panah ke tubuh Abimanyu hingga akhirnya dia gugur dalam peperangan.

\section{2) Adegan II}

Abimanyu tersadar dari lamunan akan peristiwa buruk yang dia janjikan. Kegelisahan hatinya tidak lain ialah janjinya kepada Utari. Melihat Abimanyu gelisah, datanglah Utari menghampiri dan mencoba menenangkannya. Abimanyu mencemaskan keyakinan Utari terhadap dirinya, akan tetapi Utari dengan keyakinannya menyampaikan bahwa dia tidak pernah meragukan itu semua. Biarlah waktu terus berjalan dan akan menjawab kisah selanjutnya.

\section{3) Adegan III}

Menggambarkan peristiwa romantisme antara Abimanyu dengan Utari; keduanya saling mengagumi dan terlarut dalam kisah cinta yang mendalam. Akan tetapi, Utari kemudian muncul perasaan ragu terhadap kejujuran dan kesetiaan Abimanyu. Melihat sikap Utari yang demikian membuat Abimanyu bersumpah bahwa ia rela menerima hukuman dewa dan mati mengenaskan apabila dirinya berbohong dan mengkhianati Utari.

\section{4) Adegan IV}

Tampil tokoh Utari sendirian meratapi nasib dan meluapkan kegundahannya mengenai perjalanan kisah cintanya. Menurutnya, dia merasa bahagia dapat memiliki Abimanyu meski dia tahu bahwa kehadiran Abimanyu yang membawa cinta sebenarnya sekaligus membawa luka. Namun demikian, dia sadar bahwa segala sesuatu yang terjadi di dunia selalu demikian.

Berdasarkan deskipsi Lakon Kembang Kudhup Pupus tersebut dapat dipahami bahwa alur lakonnya menggunakan alur mundur. Hal ini dapat dicermati bahwa keseluruhan rangkaian cerita sejak adegan pertama sampai ketiga sebenarnya adalah peristiwa yang telah terjadi dan sedang dialami oleh Utari pada adegan keempat. Penggunaan alur mundur dalam pakeliran konvensional sangat jarang ditemui, jika tidak boleh dianggap tidak pernah ada. Adapun garap alur lakon yang lebih bervariatif biasanya ditemukan dalam garapan-garapan Pakeliran Padat.

\section{B. Garap Karawitan Pakeliran Kembang Kudhup Pupus}

Pembahasan mengenai garap karawitan pakeliran dalam pakeliran Kembang Kudhup Pupus cukup menarik dan agak berbeda dengan garap pakeliran konvensional. Di dalam Pakeliran Sandosa unsur-unsur garap karawitan pakeliran hanya terbentuk atas gendhing dan tembang. Artinya, tidak ditemui adanya sulukan, dhodhokan, dan keprakan. Oleh karena itu, analisisnya akan berfokus pada komposisi garap gendhing dan tembang saja, sebagai sebuah sajian vokal, memiliki dua unsur yang saling terkait yakni lagu dan cakepan (Sukesi Rahayu 2018). Tembang merupakan puisi Jawa yang penyajiannya dengan cara dilagukan dan menggunakan laras sléndro dan pélog (Suyoto 2016). Hal ini sekaligus menjadi tantangan, dengan tanpa menghadirkan sulukan, dhodhokan, dan keprakan apakah capaian estetis meliputi nuksma dan mungguh dapat terpenuhi dalam sajian Pakeliran Sandosa Lakon Kembang Kudhup Pupus.

\section{1) Garap Karawitan Pakeliran Adegan I}

Adegan pertama mengisahkan tentang keberanian Abimanyu sebagai senapati Pandawa menghadapi prajurit Kurawa dalam perang Baratayuda Jaya Binangun. Akan tetapi, pada akhirnya 
dia harus menerima takdirnya gugur dalam peperangan secara mengenaskan dengan dihujani panah oleh para prajurit Kurawa. Dalam adegan ini maka dapat dipahami bahwa suasana pakeliran yang tercipta dalam adegan pertama ialah suasana agung, wibawa, gagah, dan berani yang ditampilkan melalui karakter tokoh Abimanyu. Karakter Abimanyu ini dapat dilihat pada Gambar 1 berikut.

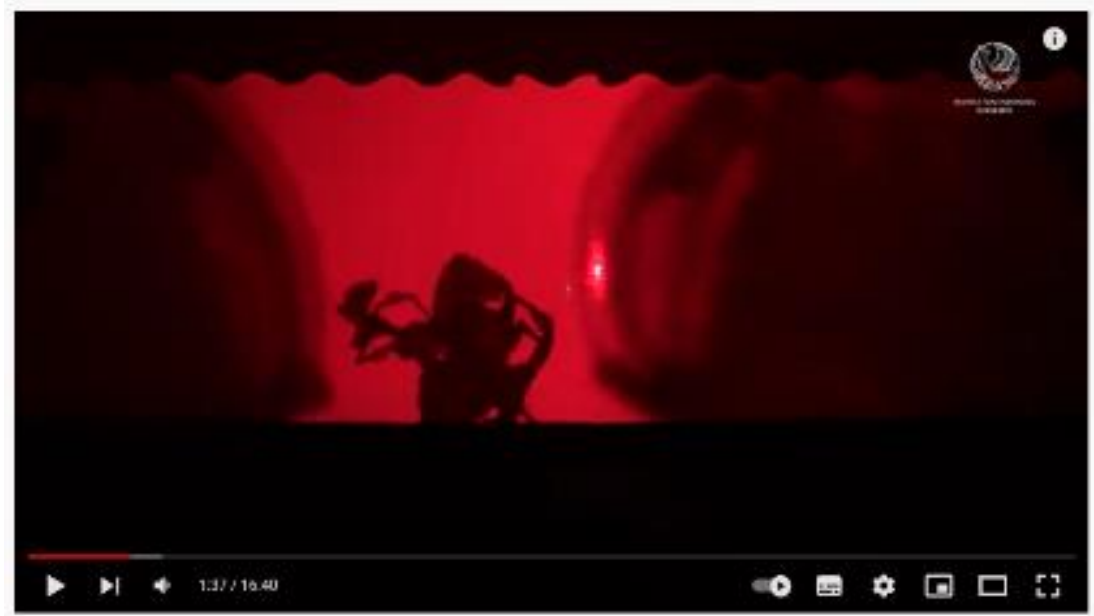

Gambar 1. Tokoh Abimanyu menaikki kuda dan menjadi senapati melawan prajurit Kurawa. (Sumber: Repro Catur Nugroho)

Namun demikian, di sisi lain adegan pertama juga menampilkan suasana kesedihan, kehancuran, dan kekejaman sebagaimana dapat dilihat pada Gambar 2 berikut.

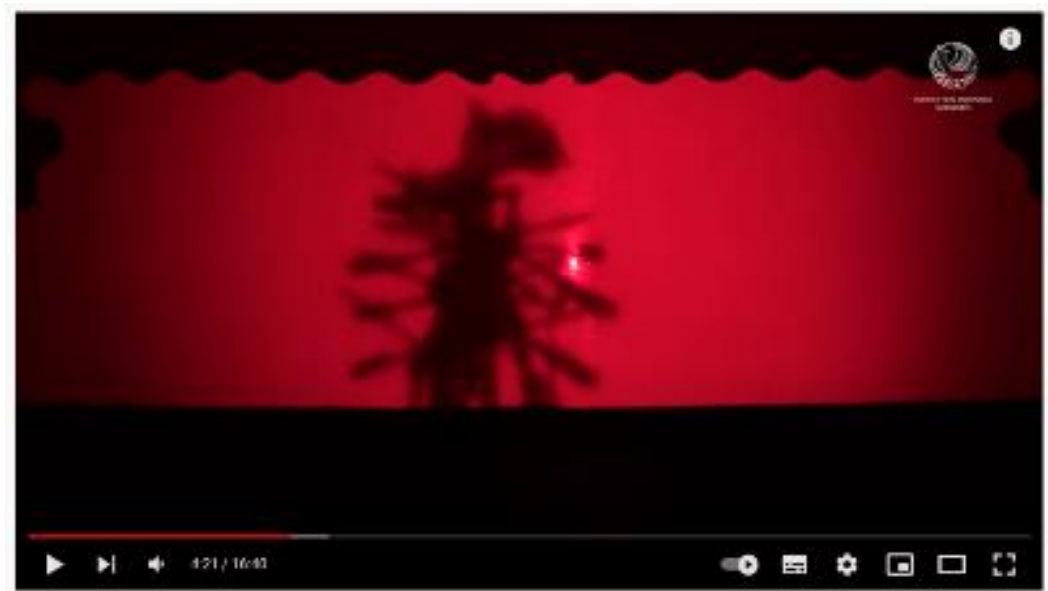

Gambar 2. Tokoh Abimanyu gugur dalam peperangan Baratayuda Jaya Binangun (Sumber: Repro Catur Nugroho)

Perpaduan suasana yang sedemikian kompleks tersebut menuntut sebuah komposisi garap karawitan pakeliran yang tepat. Sebagaimana fungsinya, bahwa karawitan pakeliran berfungsi untuk menciptakan dan mendukung suasana adegan, peristiwa lakon, dan/atau suasana batin tokoh. Adapun gendhing yang digunakan dalam adegan tersebut dapat dicermati pada gambar di bawah. 


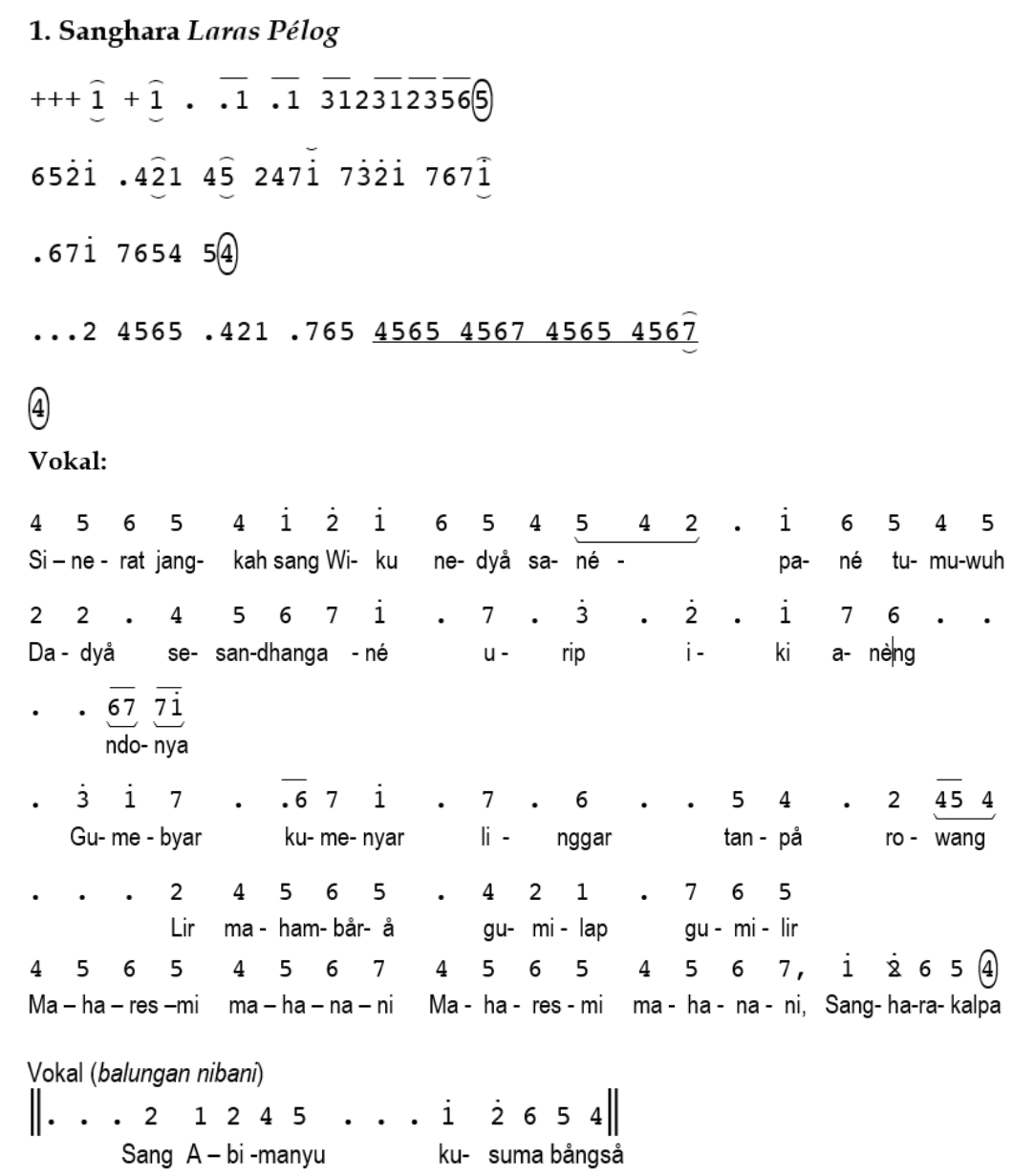

Gambar 3. Notasi Gendhing Sanghara Laras Pelog Pathet Lima.

(Sumber: Ananto Sabdo Aji)

Lagu gendhing sebagaimana dapat dicermati pada Gambar 3 dalam adegan pertama tersebut tidak memiliki struktur seperti struktur gendhing secara konvensional, tetapi menggunakan struktur pematut, yakni letak tabuhan ricikan struktural tidak terpaku pada tempat tertentu melainkan mengikuti alur melodi yang disusun. Gendhing tersebut memiliki judul Sanghara yang memiliki arti hari kehancuran. Cakepan di dalamnya menjelaskan mengenai telah menjadi tulisan alam bahwa perang besar Baratayuda Jaya Binangun akan terjadi, semua tidak dapat dihindari, dan Abimanyu akan gugur menjadi pahlawan bangsa. Pencapaian nuksma dan mungguhing garap gendhing dalam sebuah pakeliran dapat dicermati melalui kesesuaian makna dan rasa gendhing meliputi cakepan, dan melodi balungan terhadap suasana adegan di dalam lakon. Berdasarkan proses pencermatan terhadap arti cakepan atau lirik yang digunakan dalam gendhing tersebut menunjukan bahwa terdapat kesesuaian dan ketepatan antara wacana teks (cakepan) terhadap peristiwa lakon, yaitu menggambarkan terjadinya perang besar sekaligus menjelaskan tentang gugurnya Abimanyu sebagai pahlawan bangsa. Tembang yang ditulis dalam bentuk teks merupakan media berpikir dan merasa, merupakan media komunikasi estetik (Darmasti 2011). Hal demikian tercermin dalam penggalan cakepan Gendhing Sanghara berikut.

"Sang Abimanyu Kusuma Bangsa"

(Abimanyu sang bunga bangsa; pahlawan negara) 
Hal ini secara implisit merepresentasikan tercapainya konsep estetika mungguh di dalam garap karawitan pakeliran pada adegan pertama.

Berkaitan dengan estetika nuksma maka dapat dicermati melalui notasi gendhing ranjaban pada Gambar 4 di bawah ini.

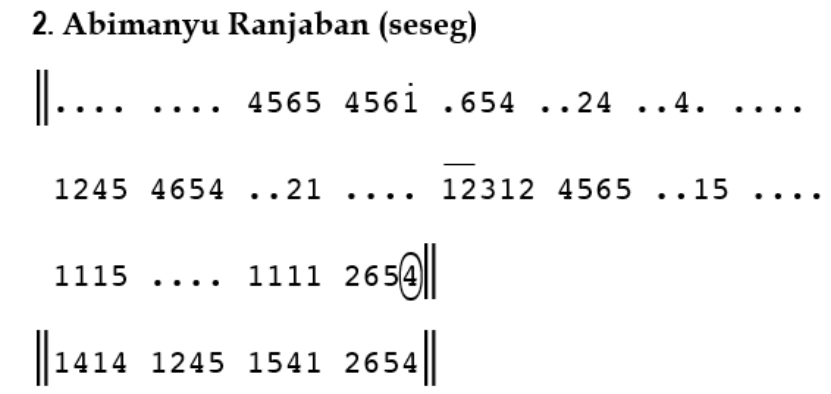

Gambar 4. Notasi Gendhing Ranjaban Laras Pelog Pathet Lima. (Sumber: Ananto Sabdo Aji)

Pencapaian nuskma bagi penghayat pakeliran menurut Sunardi ialah pencapaian katarsis, yakni sebuah puncak tujuan karya seni dalam peristiwa tragedi. Katarsis dalam hal ini diartikan sebuah kesan mendalam yang diterima oleh penonton melalui proses hayati terhadap sebuah sajian peristiwa lakon yang sedemikian rupa sehingga secara alami menimbulkan perasaan haru, kecewa, sedih, dan gembira (Sunardi 2013, 439). Berpijak atas variabel ini dapat dicermati bahwa garap Gendhing Sanghara dan Gendhing Ranjaban yang menyajikan komposisi melodi dengan wilayah nada (laras) 4 (pat) dalam gendhing pathet lima memberikan kesan minir sehingga tercipta suasana sedih. Akan tetapi, nuansa gendhing tersebut tidak sepenuhnya bermuara pada suasana sedih dengan irama yang pelan begitu saja, melainkan juga menampilkan suasana yang greget dan semangat; hal ini terimplikasi pada irama dan tempo lagu yang dinamis. Dengan demikian, rasa gendhing mampu menyentuh batin penghayat sehingga mendekati pada tataran $n u k s m a$, apabila belum bisa dianggap sepenuhnya mencapai nuksma.

\section{2) Garap Karawitan Pakeliran Adegan II}

Adegan kedua dalam Pakeliran Sandosa dengan Lakon Kembang Kudhup Pupus menggambarkan tentang kegelisahan dan kesedihan Abimanyu terhadap janji yang telah diucapkannya kepada Utari. Namun demikian, Utari mencoba meyakinkan bahwa ia tidak pernah meragukan kesetiaan dan kejujuran Abimanyu. Utari lebih memilih untuk menyerahkan takdir seiring berjalannya waktu. Dalam adegan ini suasana adegan yang dibangun ialah suasana kebimbangan dan kegelisahan hati yang dialami oleh tokoh Abimanyu. Di sisi lain, juga terdapat pembentukan suasana kepercayaan dan penyerahan diri sebagaimana dilakukan oleh tokoh Utari. Peristiwa ini tercermin dalam Gambar 5 berikut. 


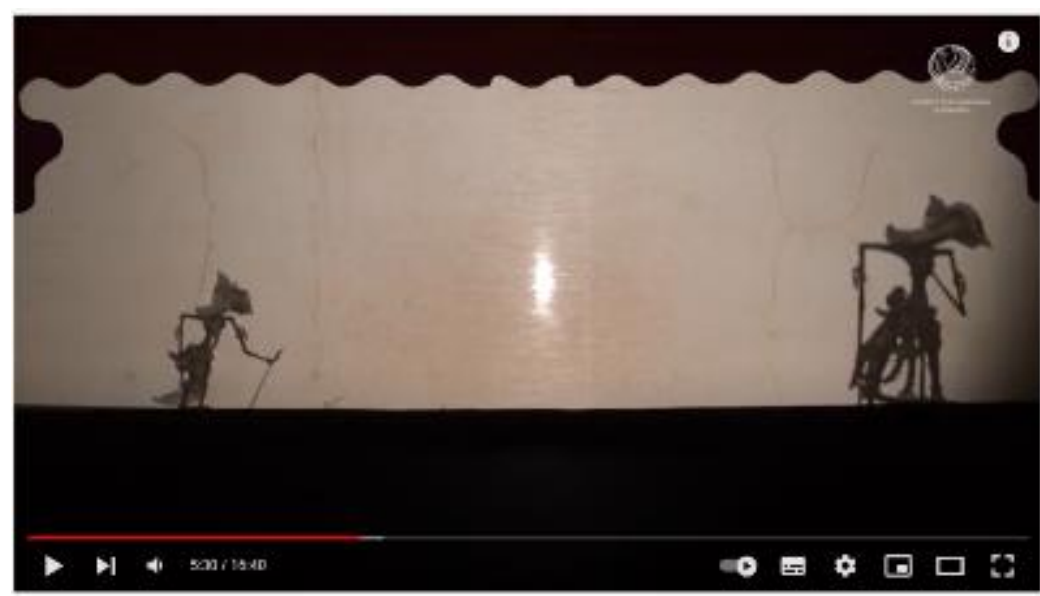

Gambar 5. Tokoh Utari menghampiri dan berusaha meyakinkan tokoh Abimanyu yang sedang gelisah (Sumber: Repro Catur Nugroho)

Dalam adegan ini maka suasana yang terbangun ialah diawali dengan nuansa gelisah, bimbang, dan sedih kemudian diakhiri suasana penyerahan diri dan keyakinan. Untuk mencermati lebih lanjut mengenai garap karawitan pakeliran yakni gendhing yang digunakan dalam adegan ini maka dapat dilihat terlebih dahulu notasi gendhing pada Gambar 6 berikut.

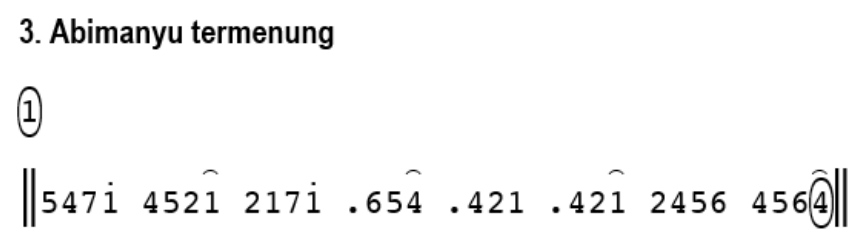

Vokal:

$$
\begin{aligned}
& \overline{\mathrm{Fi}}(1) \\
& \text { \|. } 6 \overline{.54} \text {. } .4 \underbrace{7 \bar{i}} \cdot \overline{8} i \overline{645} \text {. . } 21 \\
& \text { Semburat la- yu-la-yu sumunar a-rum }
\end{aligned}
$$

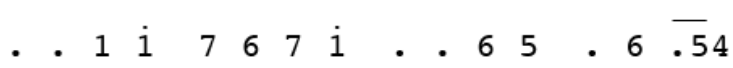

$$
\begin{aligned}
& \text { Da-dyå tetungguling ku- su- må bångså }
\end{aligned}
$$

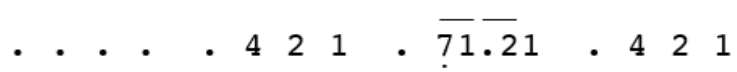

$$
\begin{aligned}
& \text { Ki-ne -pung sumpah janji prasetyå }
\end{aligned}
$$

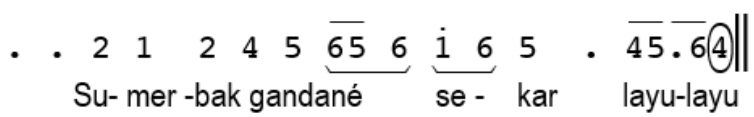

Gambar 6. Notasi Gendhing Kuning Laras Pelog Pathet Lima. (Sumber: Ananto Sabdo Aji)

Lagu di atas berjudul Kuning dengan struktur ladrang. Dalam cakepan lagu di atas menggambarkan kegelisahan Abimanyu karena sumpah yang telah diucapkannya, dia bersumpah akan mati terbunuh dengan banyak senjata jikalau memiliki wanita selain Utari, sedangkan dia sebenarnya telah menikah dengan Siti Sendari. Akan tetapi, meskipun Abimanyu gugur dalam peperangan, dia tetap menjadi kusuma bangsa. Oleh karena itu, susunan cakepan dalam gendhing 
tersebut dipandang sesuai dan selaras dengan peristiwa lakon serta suasana batin tokoh yang dialami oleh Abimanyu. Hal demikian tercermin dalam penggalan cakepan Gendhing Kuning berikut.

"...kinepung sumpah janji prasetya..."

(Abimanyu terbelenggu sumpah dan janji)

Melalui kesesuaian serta keselarasan komposisi gendhing meliputi cakepan yang sedemikian rupa maka dapat dipandang telah mungguh terhadap kebutuhan peristiwa adegan. Selanjutnya berkenaan dengan pencapaian nuksma, dapat dilihat dari susunan alur melodi yang menggunakan laras 4 (pat) dan 7 (pi) sehingga mampu menciptakan suasana gelisah dan kesedihan yang mendalam. Hal demikian semakin diperkuat dengan tempo dan irama tabuhan yang pelan, serta didukung penyajian vokal putri yang berorientasi pada rasa tembang yang sedih. Melalui serangkaian garap karawitan pakeliran yang sedemikian rupa dalam adegan kedua tersebut sehingga mampu mencapai estetika pakeliran yang mungguh dan nuskama. Adapun berkaitan dengan nuansa keyakinan dan kepercayaan yang dialami oleh Utari tersampaikan pada adegan selanjutanya, yakni adegan ketiga. Bagaimanapun juga dalam setiap adegan pada suatu pakeliran tidak berdiri sendiri, melainkan saling berkesinambungan dan memiliki keterkaitan rasa yang tidak terpisahkan.

\section{3) Garap Karawitan Pakeliran Adegan III}

Adegan ketiga merupakan lanjutan dari adegan sebelumnya, terutama menyambung terkait kepercayaan Utari kepada Abimanyu. Oleh karena itu, keyakinan yang tercipta di antara kedua tokoh membawa pada sebuah adegan romantika (pasihan). Dalam adegan ini suasana yang dibangun ialah kesan bahagia, saling menyayangi, saling mencintai, dan saling mengagumi. Peristiwa romantisme demikian dapat dilihat pada Gambar 7 berikut.

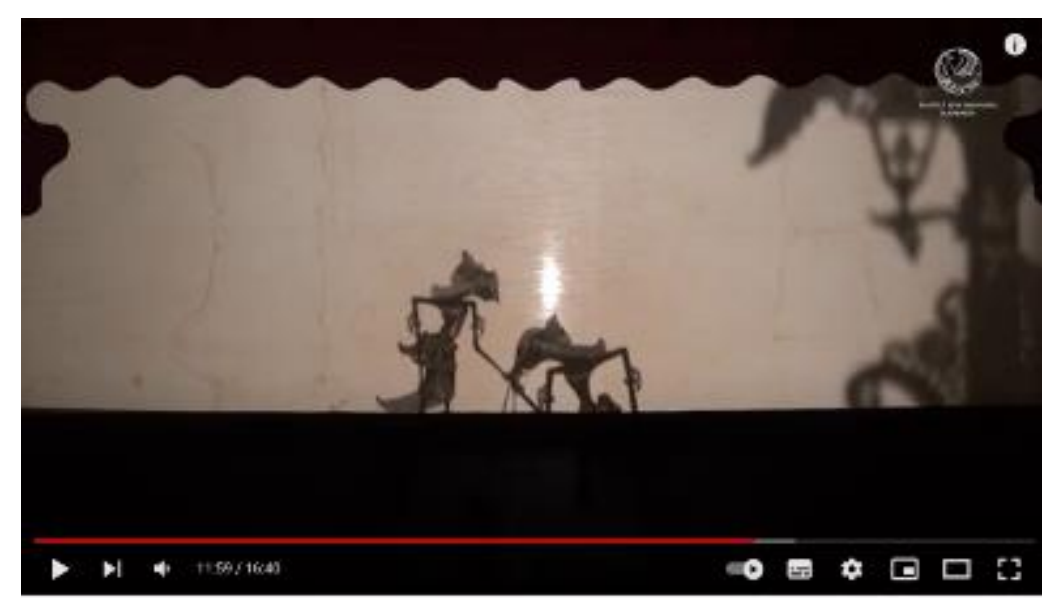

Gambar 7. Adegan pasihan; Tokoh Utari dan Abimanyu saling bermadukasih (Sumber: Repro Catur Nugroho)

Dalam adegan tersebut suasana yang dibangun ialah suasana romantisme, ketenangan, kedamaian, kebahagiaan, dan ketulusan. Adapun garap karawitan, gendhing yang digunakan ialah Ketawang Lintang sebagaimana dapat dicermati pada Gambar 8 di bawah ini. 


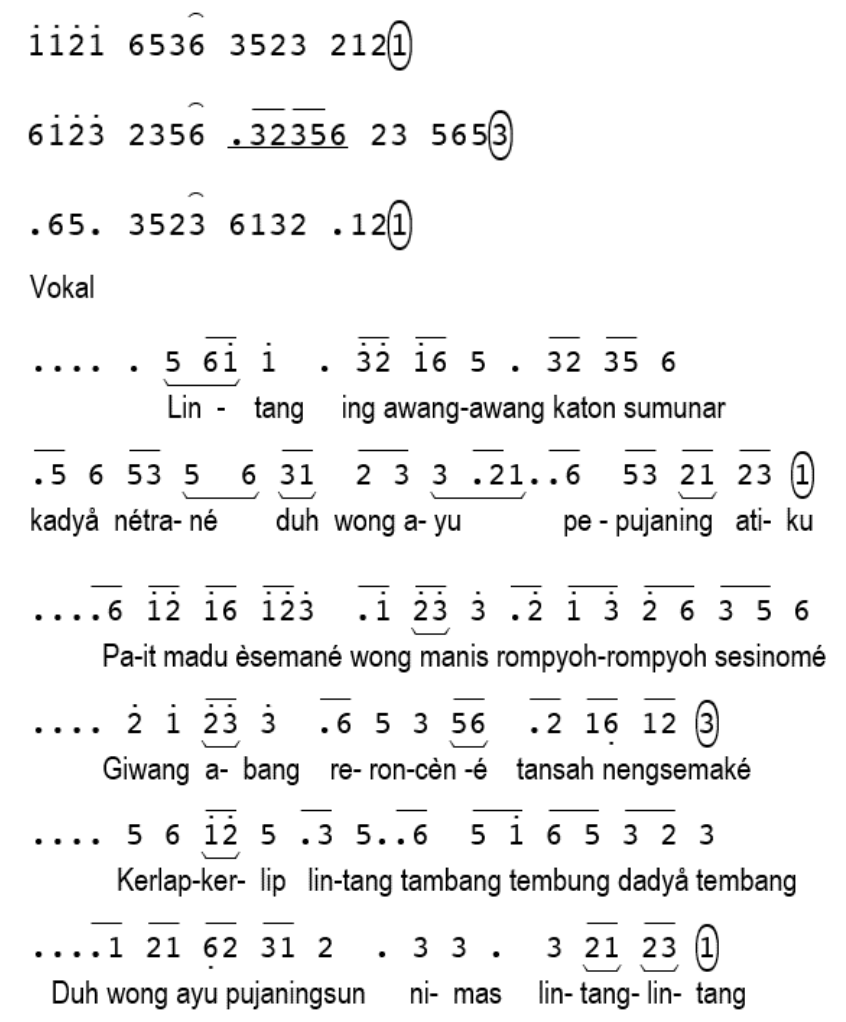

Gambar 8. Notasi Ketawang Lintang Laras Pelog Pathet Nem. (Sumber: Ananto Sabdo Aji)

Lagu di atas memiliki struktur ketawang dengan bangunan rasa musikal yang lembut, mendayu, dan manja (prenes). Ketawang Lintang digunakan untuk mendukung suasana ketika Abimanyu sedang bermadu kasih dengan Utari. Cakepan atau teks yang digunakan memiliki arti nyandra atau menjelaskan kecantikan seorang Utari bagaikan bintang bersinar terang di antariksa, senyumannya mampu membuat hati senantiasa bergetar, anting merah dan perhiasan lainnya menambah kecantikannya seperti kerlap-kerlip bintang di langit yang sangat indah sekali. Wacana puitis tersebut dicermati pada penggalan cakepan berikut.

"Lintang ing awang-awang katon sumunar,

Kadya netrane dhuh wong ayu pepujanning atiku..."

(Bintang di langit tampak bersinar, bagaikan sinar matamu duhai kekasih pujaan hatiku)

Berdasarkan penyusanan teks cakepan tersebut dapat dipahami telah memenuhi konsep estetika mungguh. Hal demikian dapat dilihat melalui kesesuaian, ketepatan, dan keselarasan antara wacana teks gendhing yang disusun terhadap kebutuhan peristiwa adegan dan suasana batin tokoh. Selanjutnya, masih dalam adegan ketiga setelah bagian romantisme disambung dengan perubahan suasana yang cukup signifikan, yaitu masu ke dalam suasana keraguan, ketegangan, dan pembuktian. Suasana keraguan ini terbentuk atas situasi Utari yang meragukan kesetiaan dan kejujuran Abimanyu, sedangkan suasana ketegangan serta pembuktian dibentuk oleh perilaku Abimanyu yang bersumpah bahwa dia akan menerima hukuman kematian yang mengenaskan 
apabila dia berbohong kepada Utari. Peristiwa sumpah Abimanyu tersebut dapat dilihat pada Gambar 9 di bawah ini.

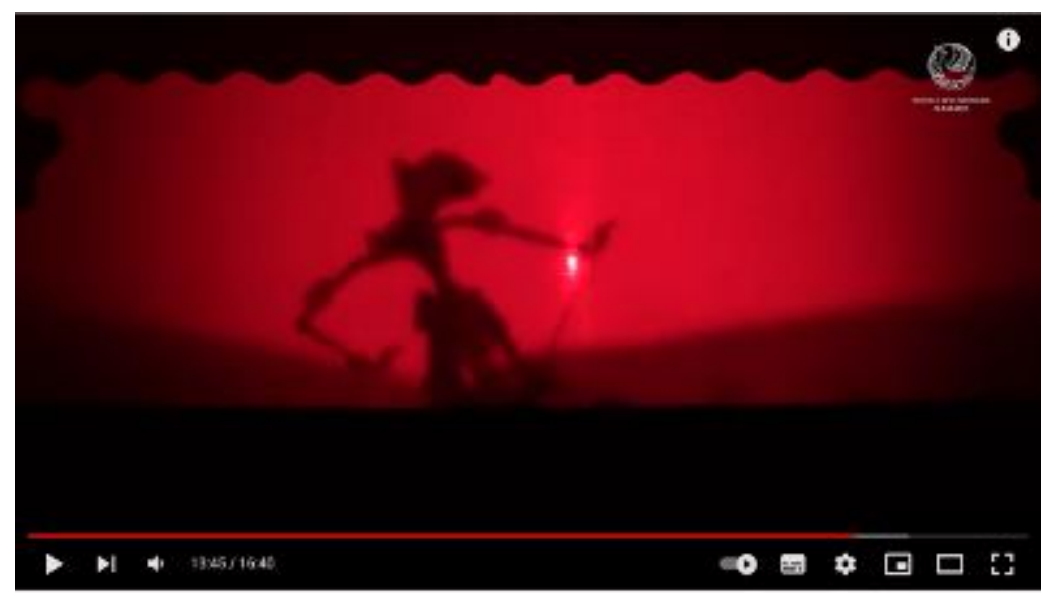

Gambar 9. Adegan Tokoh Abimanyu bersumpah (Sumber: Repro Catur Nugroho)

Berkaitan dengan suasana ragu yang dialami oleh Utari tampak bahwa garap karawitan pakeliran yang disajikan ialah suasana hening atau dengan tanpa iringan. Selanjutnya suasana tegang atau peristiwa sumpah Abimanyu menyajikan garap gendhing seperti Gambar 10 berikut ini.

\section{Abimanyu bersumpah (geteran 1) \\ $\| 11231 \mid$}

Gambar 10. Notasi Geteran 1.

(Sumber: Ananto Sabdo Aji)

Berdasarkan skema balungan pada gendhing tersebut dapat dipahami bahwa pencapaian suasana adegan yang mungguh ditempuh melalui dua pola garapan. Pertama, adegan keraguan Utari disajikan garap dengan tanpa gendhing, perlu dimengerti bahwa tanpa iringan bukan berarti tidak ada pembangunan rasa. Dalam dinamisasi sebuah grafik estetis adanya saat hening atau rasa sepi akan mampu menciptakan suasana yang lebih terasa terhadap konflik yang ditampilkan. Secara implisit hal ini sekaligus memberikan ruang secara penuh terhadap dialog wayang untuk menampilkan konflik secara tegas dan jelas. Kedua, komposisi garap karawitan yang digunakan untuk membangun suasana tegang dan memperkuat sumpah Abimanyu yakni melalui komposisi balungan tanpa vokal. Garap tersebut bertujuan untuk memberikan ruang secara utuh terhadap narasi atau dialog yang disampaikan oleh tokoh. Berdasarkan pola garapan yang demikian maka dapat dipahami telah memenuhi konsep mungguh, yakni kesesuaian dan kelerasan antara komposisi gendhing terhadap kebutuhan suasana batin tokoh.

Adapun pencapaian nuksma dalam adegan tersebut dicapai dengan mencermati indikator yang berhasil dirasakan. Penggunaan gendhing ketawang dengan nuansa pathet nem serta didukung kualitas vocal putri serta wacana teks yang puitis mampu menciptakan kesan romantis yang utuh dan memikat. Pencapaian nuksma tersebut tentu juga terkait erat dengan penyajian garap sabet pasihan yang menarik dan representative. Pencapaian nuksma dalam adegan sumpah Abimanyu 
dirasakan melalui melodi balungan yang ritmis (geteran) dan menanjak sehingga mampu menciptakan kesan dramatis yang memuncak.

\section{4) Garap Karawitan Pakeliran Adegan IV}

Dalam adegan terakhir ini menampilkan kesedihan Utari meratapi kesedihan perjalanan cintanya. Dia bahagia memiliki Abimanyu, tetapi dia juga sedih karena harus mengalami kisah cinta yang rumit. Kesedihan Utari ditambah dengan kematian Abimanyu yang tragis. Pada akhirnya dia menyerahkan kesedihannya seiring berjalannya waktu dan atas kehendak sang Tuhan. Artinya, suasana yang dibangun pada adegan ini ialah suasana kesedihan, keputus-asaan, dan penyerahan diri. Akan tetapi, di sisi lain juga dibangun suasana kebahagian Utari bahwa meskipun Abimanyu gugur dia tetap dianggap sebagai pahlawan bangsa. Persitiwa kesedihan Utari ini dapat dilihat pada

Gambar 11 berikut.

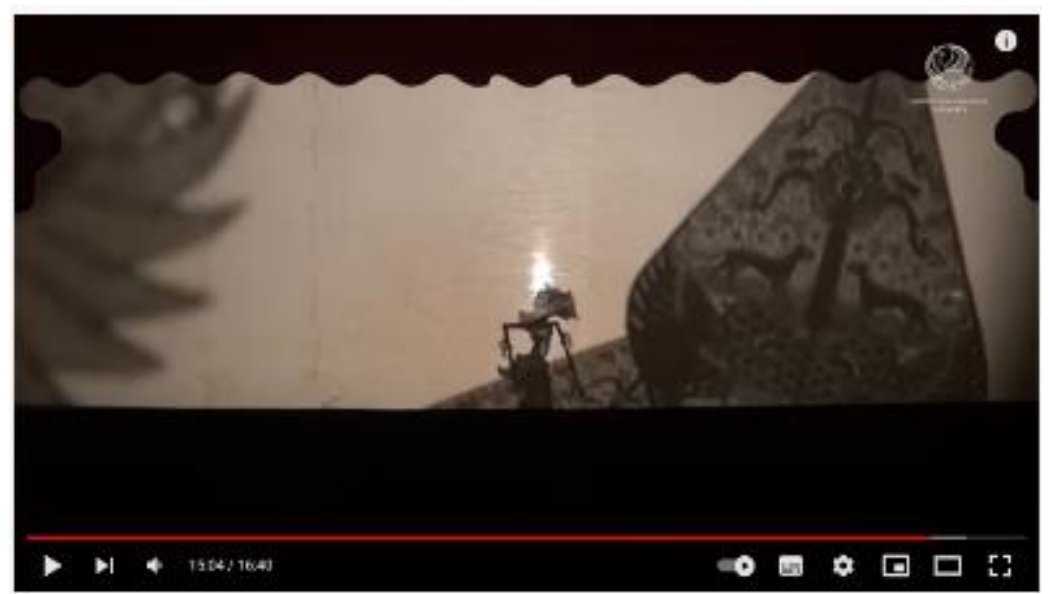

Gambar 11. Adegan Tokoh Utari bersedih meratapi peristiwa hidupnya (Sumber: Repro Catur Nugroho)

Berpijak pada peristiwa lakon tersebut, untuk mencapai suasana ini garap karawitan atau gendhing yang disajikan ialah sebagai berikut.

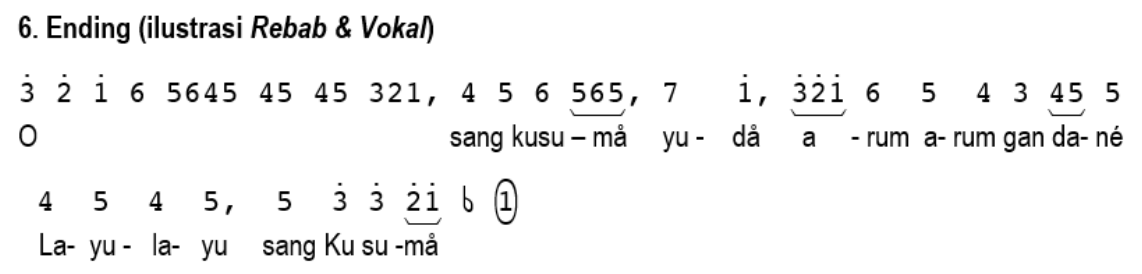

Gambar 12. Notasi Gendhing Ending. (Sumber: Ananto Sabdo Aji)

Melodi pada Gambar 12 digunakan pada penutup karya tersebut, dengan mengacu konsep pathetan yang mencoba membangun jalinan melodi vokal, rebab, dan gendèr untuk memberikan suasana musikal sedih sekaligus bahagia, karena meskipun Abimanyu gugur dalam perang tetapi menjadi pahlawan bagi bangsa dan negara. Berkaitan dengan pencapaian mungguh ialah kesesuaian antara penyusunan teks cakepan dengan peristiwa lakon, yakni kesedihan Utari atas kematian Abimanyu sebagai pahlawan bangsa. Hal demikian dapat dicermati pada cakepan berikut. 
"sang kusuma yuda arum-arum gandane,

Layu layu sang kusuma"

(Sang pahlawan bangsa harum namanya, telah gugur sang pahlawan)

Adapun berkaitan dengan pencapaian nuksma pada garap gendhing adegan tersebut dapat dicermati pada terciptanya kesan sedih yang mendalam. Kesan ini dapat diraih melalui melodi lagu dengan nuansa perpaduan nada (laras) 4 (pat) dan 7 (pi) dalam komposisi balungan gendhing instrumental yang disajikan. Lebih dari itu, pencapaian nuksma semakin terasa dengan pola garapan instrumental yang menyajikan perpaduan antara vokal dengan instrument rebab dan gender yang sedemikian rupa. Kedudukan, peran, dan fungsi vokal di dalam karawitan tidak dapat dikesampingkan (Saraswati 2013; Aji 2019), untuk membangun musikal supaya dapat mencapai rasa pada puncaknya.

\section{Kesimpulan}

Berdasarkan analisis yang telah ditempuh berkaitan dengan garap karawitan pakeliran dalam Pakeliran Sandosa Lakon Kembang Kudhup Pupus maka dapat ditarik simpulan sebagai berikut. Pertama, garap karawitan pakeliran meliputi garap komposisi gendhing dan tembang sejak adegan awal hingga akhir dapat dipahami mencapai tataran estetika pakeliran yang mungguh. Hal demikian dapat dilihat dengan terciptanya ketepatan, keselarasan, dan kesesuaian antara komposisi garap karawitan pakeliran meliputi gendhing dan tembang terhadap kebutuhan peristiwa lakon dan suasana batin yang dialami oleh tokoh wayang. Kedua, pencapaian kesan katarsis estetika pakeliran nuksma dalam bingkai garap karawitan pakeliran dapat dirasakan melalui pola garapan melodi serta lagu gendhing dan tembang yang disusun sedemikian rupa dengan memperhatikan kesesuaian antara teknis penyuaraan, tabuhan, dan pengaturan grafik musikal yang berorientasi pada dinamisasi rasa gendhing.

\section{Daftar Pustaka}

Ahimsa-Putra, Heddy Shri. 2000. Ketika Orang Jawa Nyeni. Yogyakarta: Galang Press.

Aji, Ananto Sabdo. 2019. “Konsep Mandheg Dalam Karawitan Gaya Surakarta." Resital : Jurnal Seni Pertunjukan 20: 2.

- - - 2020. "Skema Mandheg Dalam Struktur Gendhing Gaya Surakarta." Keteg: Jurnal Pengetahuan, Pemikiran Dan Kajian Tentang "Bunyi" 20 (1).

Atmojo, Bambang SRI. 2010. “Kendhangan Pamijen Gending Gaya Yogyakarta.” Resital: Jurnal Seni Pertunjukan 11 (1).

Darmasti. 2011. "Kidung Kandhasanyata Sebagai Ekspresi Estetik Pesinden Wanita Mardusari." Harmonia: Journal of Arts Research and Education 11 (2).

Irawati, Eli. 2016. "Transmisi Kelentangan Dalam Masyarakat Dayak Benuaq." Resital : Jurnal Seni Pertunjukan 17: 1-25.

Monks, A.M.P., and F.J. an Knors Rahayu. 2006. Psikologi Perkembangan Pengantar Dalam Berbagai Bagiannya. Edited by Siti Rahayu. Yogyakarta: Gadjah Mada University Press. 
Murtiyoso, Bambang. 1995. “Faktor-Faktor Pendukung Popularitas Dalang.” Universitas Gadjah Mada.

Nugroho, Catur. 2021a. “Konsep Garap Pakeliran Wayang Tunggal Lakon Sudamala Sajian Ki Purbo Asmoro." Lakon XVIII: 1-14.

- - - 2021b. “Udanagara Tancepan Konsep Estetika Sabet Dalam Pakeliran Gaya Surakarta." Institut Seni Indonesia Surakarta.

Purwanto, Djoko. 2011. Estetika Karawitan. Surakarta: Jurusan Seni Karawitan ISI Surakarta.

Rahayu, Sukesi. 2018. "Estetika Wangsalan Dalam Lagu Sindhenan Karawitan Jawa." Gelar : Jurnal Seni Budaya 16 (1).

Saraswati, Batari Ayu. 2013. “Perjalanan Hidup Dan Kreatifitas Sang Pesindhèn.” Dewa Ruci 8 (2): 157-77.

Sarwanto. 2008. Pertunjukan Wayang Kulit Purwa Dalam Ritual Bersih Desa Kajian Fungsi Dan Makna. Surakarta: ISI Press Surakarta.

Setyawan, Sigit. 2018. “Kendangan Pinantut Dalam Sajian Klenengan.” Gelar : Jurnal Seni Budaya 16 (1).

Sunardi. 2004. "Pakeliran Sandosa Dalam Perspektif Pembaharuan Pertunjukan Wayang." STSI Surakarta.

- - - 2012. "Nuksma Dan Mungguh: Estetika Pertunjukan Wayang Purwa Gaya Surakarta." Universitas Gadjah Mada.

- - - 2013. Nuksma Dan Mungguh: Konsep Dasar Estetika Pertunjukan Wayang. Surakarta: ISI Press Surakarta.

Suyoto. 2016. “Sukon Wulon Dalam Tembang Macapat: Studi Kasus Tembang Asmaradana." Keteg : Jurnal Pengetahuan, Pemikiran Dan Kajian Tentang "Bunyi" 16 (1).

Teguh. 2017. “Ladrang Sobrang Laras Slendro Patet Nem.” Resital: Jurnal Seni Pertunjukan 18 (2): 103-12. 